\begin{tabular}{|l|l|l||}
\hline \multicolumn{2}{|c|}{ PublisherInfo } \\
\hline \hline PublisherName & $:$ & BioMed Central \\
\hline \hline PublisherLocation & $:$ & London \\
\hline \hline PublisherImprintName & $:$ & BioMed Central \\
\hline \hline
\end{tabular}

\title{
Information and services for the arthritis community
}

\begin{tabular}{|l|l|l||}
\hline \multicolumn{2}{|c|}{ ArticleInfo } \\
\hline \hline ArticleID & $:$ & 27 \\
\hline \hline ArticleDOI & $:$ & $10.1186 /$ ar-2000-2-webreport0007 \\
\hline \hline ArticleCitationID & $:$ & 0007 \\
\hline \hline ArticleSequenceNumber & $:$ & 23 \\
\hline \hline ArticleCategory & $:$ & Web Report \\
\hline ArticleFirstPage & $:$ & 1 \\
\hline \hline ArticleLastPage & $:$ & 3 \\
\hline \hline & & RegistrationDate : 2000-2-25 \\
\hline ArticleHistory & $:$ & OnlineDate \\
\hline \hline ArticleCopyright & $:$ & Current Science Ltd2000-2-25 \\
\hline \hline ArticleGrants & $:$ & \\
\hline \hline ArticleContext & $:$ & 130752211 \\
\hline \hline
\end{tabular}




\section{Overview}

The Canadian Arthritis Network (CAN) is one of five sites hosted by Arthritis Canada, a digital gateway to the key organisations and stakeholders within the Canadian arthritis community. The network comprises 120 scientists and clinicians from 44 institutions in Canada, and is mainly funded by the federal Networks of Centres of Excellence, with other revenue coming from arthritis societies, industrial partners and venture capitalists. The stated aim of CAN is 'to bring together scientists, clinicians and the arthritis community to tackle fundamental questions about arthritis and to respond to the needs of Canadian arthritis sufferers'.

\section{Overview}

This newly-created site (launched November 1999) contains a vast amount of information for both professionals and patients, and is well-organised, attractive and easy to navigate. There are so many sections that I will only give a brief overview here.

The site provides ongoing coverage of all current CAN research projects, which are divided into five themes: genetic and inflammatory mediators; cellular and molecular biology of joint tissues; bioengineering; diagnostics and therapeutics; and methodologies and outcomes. CAN's Clinical Trials Network is in the process of setting up a national registry of patients with rheumatoid arthritis or osteoarthritis. The network can provide research and consulting services, models of disease management and screening systems, databases of genetic/transgenic animal models, biotech start-up, and training schemes. The 'product showcase' section describes in detail those products developed as a result of CAN research, and also lists current patents and licenses. The 'info exchange' pages include a calendar of events, links to publications (including $A+$, the arthritis sufferers' journal), a discussion forum, financial information and press releases. The site also includes an employment section, which lists both corporate and academic opportunities.

\section{Other}

The site is available both in French and English. There is a 'members only' section that contains information on research, training, administration, a library and discussion forum, and is only available to 
the 120 core members of CAN. Pages are not individually named so bookmarks will always take you to the homepage.

\section{Evaluation}

CAN is an ambitious concept, and aims to expand and become a world-leader in developing new technologies, providing knowledge-based services, and enhancing patient's quality of life. It has substantial financial backing, plus access to a cross-disciplinary panel of top scientists and clinicians involved in arthritis research. Although rather thin on useful content at the time of review, I would expect this new site to quickly develop into an invaluable resource for everyone in the international arthritis research community.

\section{References}

1. Canadian Arthritis Network. [http://www.arthritis.ca/can/]

This PDF file was created after publication. 